\begin{tabular}{|c|c|}
\hline Title & Suppression of pyrite oxidation by carrier microencapsulation using Silicon and Catechol \\
\hline Author(s) & Jha, Rani Kumari Thakur; Satur, Jacqueline; Hiroyoshi, Naoki; Ito, Mayumi; Tsunekawa, Masami \\
\hline Citation & $\begin{array}{l}\text { Mineral Processing and Extractive Metallurgy Review: An International Journal, 33(2), 89-98 } \\
\text { https://doi.org/10.1080/08827508.2011.562946 }\end{array}$ \\
\hline Issue Date & 2011-12-07 \\
\hline Doc URL & http:/hdl.handle.net/2115/50818 \\
\hline Rights & $\begin{array}{l}\text { This is an A uthor's A ccepted Manuscript of an article published in Mineral Processing and Extractive Metallurgy } \\
\text { Review: An International Journal, 33(2), } 07 \text { Dec 2011, pages 89-98, copyright T aylor \& Francis, avail able online at: } \\
\text { http://www.tandfonline.com/10.1080/08827508.2011.562946. }\end{array}$ \\
\hline Type & article (author version) \\
\hline File Information & MPEMR33-2_89-98.pdf \\
\hline
\end{tabular}

Instructions for use 


\title{
Suppression of pyrite oxidation by carrier microencapsulation using Si and Catechol
}

\author{
Rani Kumari Thakur JHA * ${ }^{l}$, Jacqueline SATUR ${ }^{l}$, Naoki HIROYOSHI ${ }^{1}$, Mayumi ITO ${ }^{l}$, and Masami \\ TSUNEKAWA ${ }^{1}$ \\ ${ }^{1}$ Laboratory of Mineral Processing and Resources Recycling, Graduate School of Engineering, \\ Hokkaido University, Kita 13 Nishi 8, Kita-Ku, Sapporo, Hokkaido 060-8628, Japan
}

Corresponding author: Rani - rani@eng.hokudai.ac.jp, phone \# 0117066315

\section{ABSTRACT}

Acid mine drainage (AMD) is formed from the natural oxidation of sulfide minerals such as pyrite, $\mathrm{FeS}_{2}$. Prevention of acid mine drainage is very important and several techniques are currently being investigated for the treatment and abatement of AMD. This paper proposes carriermicroencapsulation (CME) using Si-catechol complex- $\mathrm{Si}(\mathrm{cat})_{3}{ }^{2-}$ - for preventing pyrite oxidation. In $\mathrm{CME}$, the water soluble organic carrier- catechol and metal ion-Si makes a complex e.g., tris-catecholato complex of $\mathrm{Si}^{4+}$, which oxidatively decomposes on pyrite surface and forms a stable oxide or hydroxide e.g., $\mathrm{Si}(\mathrm{OH})_{4}$ or $\mathrm{SiO}_{2}$ layer on the pyrite surface as a protective coating against pyrite oxidation.

To demonstrate the effect of $\mathrm{CME}$ using $\mathrm{Si}(\mathrm{cat})_{3}{ }^{2-}$ on pyrite oxidation, shaking-flask leaching experiments of pyrite without and with CME treatment were performed. Significant halt in $\mathrm{pH}$ drop was observed after the CME treatment of pyrite. The CME coating was found very effective even at low $\mathrm{Si}$ (cat) ${ }_{3}{ }^{2-}$ concentration of $1 \mathrm{~mol} \mathrm{~m}^{-3}$ and $5 \mathrm{~mol} \mathrm{~m}^{-3}$. The amounts of $\mathrm{Fe}$ and $\mathrm{S}$ leached were lower from the pyrite with CME treatment than without CME treatment, indicating that CME using Si and catechol is effective in suppressing pyrite oxidation.

The effect of $\mathrm{pH}$ and presence of microorganism was also evaluated. The CME coating was found very effective even in acidic $\mathrm{pH}$ range. The CME treatment suppressed pyrite oxidation even in the presence of iron oxidizing microorganism. Presence of $\mathrm{Si}$ and $\mathrm{O}$ on the residue pyrite surface in SEM-EDX analysis supported the sustainability of CME coating at acidic $\mathrm{pH}$.

KEYWORDS: Acid mine drainage; pyrite oxidation; carrier micro encapsulation

\section{INTRODUCTION}

Exposure of the sulfide bearing wastes such as pyrite $\left(\mathrm{FeS}_{2}\right)$ to the oxidizing environment results to a severe environmental problem called acid mine drainage (AMD): it is defined as a very low $\mathrm{pH}$ leachate formed by the oxidation of sulfide minerals contained in the mining and mineral processing waste [Kafui and Egiebor, 1995]. The problem becomes more severe when the toxic low pH leachate, from the mine site, contaminates downstream water bodies [Fillion et.al. 1990].

Pyrite oxidation occurs in the presence of oxygen and water and it is catalyzed by the iron oxidizing bacteria: Acidithiobacillus ferrooxidans. The $\mathrm{Fe}^{2+}$ ion formed as oxidation product can be further oxidized to $\mathrm{Fe}^{3+}$ that enhances the further oxidation of pyrite and lowers the $\mathrm{pH}$ at the same time [Temple and Colmer 1951]. Since AMD is a naturally "ongoing" process, once the process starts acidic water is continually formed even after mine closure and the release can be for centuries or even millennia [Logsdon, 2002]. The extent of the problem can be imagined from its total worldwide liability, which is likely to be in excess of 10000 millions of US dollars. In US alone the mining industries spend more than US $\$ 1$ million every day to treat AMD water [Brown et.al. 2002]. 
A number of methods reported in the past tried to inhibit the pyrite oxidation by physical, chemical, or biological means. Some of the reported approaches for remedies of AMD include:- adding low cost lime to neutralize the acid and precipitate heavy metals as hydroxides, underwater disposal of sulfide waste [Robertson, 1994 ], use of nonpermeable liners such as -- plastic, clay, and asphalt to provide a safe anoxic setting for storing sulfide waste [Swanson et.al. 1997], the consumption of bactericides to reduce the population of catalyzing bacteria and hence diminish the rate of pyrite oxidation [Dugan, 1987], complexation of ferric ions in solution or at the pyrite surface with hydroxyl functional group to make pyrite surface unavailable for oxidation [Chander and Zhou 1992], phosphating in low and high temperature [Kafui and Egiebor, 1995], and coating of the pyrite surface with phospholipids or ferric- phosphate to inhibit oxygen diffusion to pyrite surface [Kargbo et.al. 2004, Evangelou, 2001]. However, problems associated with the mentioned approaches made them difficult to be widely accepted as AMD remediation techniques. For instance, the traditional approach for AMD treatment, addition of low cost lime, has big issue on sludge disposal, as the sludge produced by lime neutralization process is voluminous with low solid content and low chemical stability, has no economic value, and requires specially designed landfill for disposal [Murdock et. al. 1994, Mc Donald et. al. 2006]. Liner technology- by using clay or other nonpermeable liners to design safe disposal site for sulfide waste can be cost- prohibitive but ineffective well due to the liners' deterioration with time.

Recently, an approach to coat the pyrite surface by titanium or silicon oxides known as carrier micro encapsulation (CME) of pyrite was reported by the present authors [Satur et.al.2007, Jha et.al.2008]. In CME, pyrite is treated with aqueous solutions of metal ion $\left(\mathrm{Ti}^{4+}\right.$ or $\left.\mathrm{Si}^{4+}\right)$ complex with organic carrier such as catechol (cat), i.e. $\left[\mathrm{Si}(\mathrm{cat}){ }_{3}{ }^{2-}\right]$ or $\left[\mathrm{Ti}(\mathrm{cat}){ }_{3}{ }^{2-}\right]$. The complex is adsorbed on the pyrite surface and oxidatively decomposes on the surface, releasing metal ions that are hydrolyzed to make a thin layer of metal oxide or hydroxide. It is found that the CME coating on pyrite surface suppresses floatability of pyrite during coal-processing. CME, in fact, seems highly promising to reduce the $\mathrm{SO}_{2}$ emission (due to combustion of pyrite with coal) because of its effective separation of pyrite from coal [Jha et.al. 2008].

In the present work, the authors had evaluated the effect of CME on pyrite oxidation using triscatecholato complex of $\mathrm{Si}^{4+}\left[\mathrm{Si}(\mathrm{cat})_{3}{ }^{2-}\right.$. Shaking flask leaching experiments were carried out to verify the effect of CME on pyrite oxidation with $\mathrm{pH}$ and amounts of Fe and $\mathrm{S}$ leached as indicators. The result confirms that CME coating is able to slow down the pyrite oxidation rate successfully.

\section{MATERIALS AND METHODS}

\section{Material:}

A ground pyrite sample from Peru was used in this experiment. The pyrite sample was crushed in jaw crusher and grinded in ball mill followed by sieving to obtain the 53 to $75 \mu \mathrm{m}$ size fractions. The sieved pyrite was washed following the procedures of Sasaki et.al.1995: washing with ethanol with ultrasonic vibration initially applied on the solution for $30 \mathrm{~s}$, then washing with $1 \mathrm{kmol} \mathrm{m}^{-3} \mathrm{HNO}_{3}$ to create fresh pyrite surfaces, distilled water to wash off the nitric acid, and acetone to facilitate drying, and finally vacuum drying the washed pyrite for $24 \mathrm{~h}$ [Sasaki et al, 1995]. The tris-catecholato complex of $\mathrm{Si}^{4+}\left[\mathrm{Si}(\mathrm{cat})_{3}{ }^{2-}\right]$ for CME treatment was prepared by mixing $0.142 \mathrm{~g}$ of $\mathrm{Na}_{2} \mathrm{SiO}_{3} .9 \mathrm{H}_{2} \mathrm{O}$ and $0.165 \mathrm{~g}$ of

catechol in $10 \mathrm{~cm}^{3}$ distilled water. This solution contains $5 \mathrm{~mol} \mathrm{~m}^{-3} \mathrm{Si}(\mathrm{cat})_{3}{ }^{2-}$. The solution pHs were maintained by adding $\mathrm{HCl}$ or $\mathrm{NaOH}$ solution.

\section{Methods:}

\section{Carrier micro encapsulation treatment}


$1 \mathrm{~g}$ of pyrite samples are shaken with the different known concentration of $10 \mathrm{~cm}^{3}$ of Si(cat) $3^{2-}$ solution inside water bath shaker for desired time period. The shaking amplitude of water bath shaker is $4 \mathrm{~cm}$; and the frequency is $120 \mathrm{~min}^{-1}$. The pyrite sample was filtered and washed for shaking flask experiments.

\section{Long and short time shaking flask experiments}

The effect of CME on pyrite oxidation was investigated with different concentrations of $\mathrm{Si}(\mathrm{cat}){ }_{3}{ }^{2-}$ by shaking flask leaching experiments at long and short time periods. For reference, the same experiment was carried out with the pyrite without any CME treatment.

The long time shaking flask experiment (one month) was carried out on $2 \mathrm{~g}$ of CME treated pyrite shaken in $20 \mathrm{~cm}^{3}$ of distilled water under aerobic condition using a water bath shaker at $25^{\circ} \mathrm{C}$. The shaking amplitude of the water bath shaker was $4 \mathrm{~cm}$; and the frequency was $120 \mathrm{~min}^{-1}$. At fix intervals of 1 week, the $2 \mathrm{~cm}^{3}$ of leachate were sampled from the flask to measure the $\mathrm{pH}$ and ORP and the Fe and $\mathrm{S}$ contents of the leachate by ICP-AES.

To determine the effectiveness of the CME treatment at acidic conditions, shaking flask experiment for short time (one week) was done on $1 \mathrm{~g}$ of pyrite shaken along with $\mathrm{Si}(\mathrm{cat}){ }_{3}{ }^{2-}$ and $10 \mathrm{~cm}^{3}$ of distilled water adjusted at different $\mathrm{pH}$ conditions from $0-6$ by adding $\mathrm{HCl}$.

Another long time shaking flask experiment (4 weeks) was carried out on $1 \mathrm{~g}$ of CME treated pyrite along with $5 \mathrm{~mol} \mathrm{~m}^{-3}$ of $\mathrm{Si}(\mathrm{cat})_{3}{ }^{2-}$ and acidithiobacillus ferrooxidans acidophilic bacteria. At fixed intervals of 1 week, the flask was removed from the shaker to measure the $\mathrm{pH}$ and ORP of the leachate.

After the desired time of interval of leaching experiment, solid-liquid filtration was carried out and the filtrate thus obtained was analyzed by Inductively Coupled Plasma Atomic Emission Spectrometry (ICPAES) to measure the Fe, and S content in it. The surface morphologies of the untreated and CME treated pyrite were analyzed by SEM- EDX.

\section{RESULT AND DISCUSSION}

Catechol is a week diprotic acid (pKa1=9.2. $\mathrm{pKa}_{2}=13$ ) and therefore can remain in the undissociated form over a wide $\mathrm{pH}$ range [Rodriguez et. al. 1996]. It can form a triscatecholato silicon(IV) complex with $\mathrm{Si}^{4+}-\mathrm{Si}(\mathrm{cat})_{3}{ }^{2-}-$ [ Kansal and Laine, 1994, Caulfield et.al. 2001]. In the present work, triscatecholato silicon (IV) complex $-\mathrm{Si}(\mathrm{cat})_{3}{ }^{2-}$ - was used for making a thin stable layer of $\mathrm{SiO}_{2}$ or $\mathrm{Si}$ $(\mathrm{OH})_{4}$ on the pyrite surface to inhibit pyrite oxidation. In carrier micro encapsulation $(\mathrm{CME}), \mathrm{Si}(\mathrm{cat})_{3}{ }^{2-}$ complex is oxidatively decomposed on the pyrite surface and the released $\mathrm{Si}^{4+}$ ion hydrolyses to form a thin layer of $\mathrm{SiO}_{2}$ or $\mathrm{Si}(\mathrm{OH})_{4}$ on the pyrite surface [Jha et.al. 2008].

The reaction involved in AMD can be illustrated as:

$$
\begin{aligned}
& \mathrm{FeS}_{2}+7 / 2 \mathrm{O}_{2}+\mathrm{H}_{2} \mathrm{O} \rightarrow \mathrm{Fe}^{2+}+2 \mathrm{SO}_{4}{ }^{2-}+2 \mathrm{H}^{+\ldots} \\
& \mathrm{FeS}_{2}+2 \mathrm{H}^{+}+1 / 2 \mathrm{O}_{2} \rightarrow \mathrm{Fe}^{2+}+2 \mathrm{~S}+\mathrm{H}_{2} \mathrm{O} \ldots \ldots
\end{aligned}
$$

The $\mathrm{Fe}^{2+}$ produced can be further oxidized by $\mathrm{O}_{2}$ into $\mathrm{Fe}^{3+}$, which in turn will precipitate as $\mathrm{Fe}(\mathrm{OH})_{3}$ and lower the $\mathrm{pH}$ at the same time [Evangelou,1995]. Thus, the $\mathrm{pH}$ and the amounts of $\mathrm{Fe}$ and $\mathrm{S}$ present in the solution are the main indicators of AMD. Therefore, in this paper the effect of CME on $\mathrm{pH}$ drop and Fe and S leachability was analyzed.

The effect of CME on pyrite oxidation was investigated with different concentrations of $\mathrm{Si}(\mathrm{cat})_{3}{ }^{2-}$ by shaking flask leaching experiments. For reference, the same experiment was carried out without CME treatment. 
Figure 1(A)(B)(C) shows the result of the one month shaking flask experiment as indicated by the final $\mathrm{pH}$ of leachate, amount of $\mathrm{Fe}$ and $\mathrm{s}$ present in leachate after four weeks as a function of concentration of $\mathrm{Si}(\mathrm{cat})_{3}{ }^{2-}$. The initial $\mathrm{pH}$ of the leachate was around 3.5 and after four weeks the $\mathrm{pH}$ of leachate for untreated pyrite dropped down to 1.7 while the $\mathrm{pH}$ for the CME-treated pyrite $\left(\mathrm{Si}\right.$ (cat) ${ }_{3}{ }^{2-}$ concentrations of 1 to $10 \mathrm{~mol} \mathrm{~m}^{-3}$ ) was higher than 2.7. CME treatment with $5-10 \mathrm{~m} \mathrm{~mol}^{-3}$ of Si(cat) ${ }_{3}{ }^{2-}$ demonstrated same capacity to halt the $\mathrm{pH}$ drop. In Figure 1(B) and 1(C) the amount of Fe and $\mathrm{S}$ present in leachate after the four week of leaching is presented and it shows that the amount of Fe and $\mathrm{S}$ present in the leachate of CME treated, ( $\mathrm{Si}(\mathrm{cat})_{3}{ }^{2-}$ concentrations of 1 to $10 \mathrm{~mol} \mathrm{~m}^{-3}$ ), pyrite is very low in comparison of that for the non treated pyrite leachate. For the succeeding experiments, the concentration of $\mathrm{Si}(\mathrm{cat})_{3}{ }^{2-}$ are decided to be kept at $5 \mathrm{~mol} \mathrm{~m}^{-3}$.

Figure 2 shows the $\mathrm{pH}, \mathrm{Fe}$ and $\mathrm{S}$ contents in the leachate obtained at one week intervals for one month shaking flask experiment. In Figure 2(A) the $\mathrm{pH}$ trend with leaching time is presented. The result shows that the $\mathrm{pH}$ of the leachate of the pyrite with CME treatment is higher than that of the leachate of the untreated pyrite. The $\mathrm{pH}$ drop for un-treated pyrite was significant and after four weeks it was recorded 1.7. on the other hand, the $\mathrm{pH}$ of the leachate of the pyrite with CME treatment was 3.2 over the one month experiment. Figures 2 (B) and (C) show the Fe and S concentrations (in ppm) in the leachate, respectively. The amount of Fe and $\mathrm{S}$ leached from the CME treated pyrite is significantly less in comparison to that of from un-treated pyrite after one month leaching. Figure 2(B) depicts that after 30 days of leaching 160ppm of Fe ion was present in the leachate of non-treated pyrite, on the other hand only 60ppm of Fe ion was present in the leachate of CME treated pyrite, indicating that suppression in Fe leaching behavior is achieved by CME treatment of pyrite. Suppression of sulphur leaching is also observed for CME treated pyrite: Figure 2(C) depicts that after 30 days leaching 20ppm of S ion was present in the leachate of non-treated pyrite, while the leached amount of $\mathrm{S}$ ion for CME treated pyrite leachate sample was only $2 \mathrm{ppm}$. In addition, the higher mass ratio of Fe and $S$ in the leachate could be explained based on the equation (II) i.e. the formation of elemental sulfur on pyrite oxidation. These results imply that the $\mathrm{SiO}_{2} / \mathrm{Si}(\mathrm{OH})_{4}$ layer formed on the pyrite surface by the CME treatment confirmed itself as a barrier layer against pyrite oxidation by bringing a halt in $\mathrm{pH}$ drop and by controlling the leaching of $\mathrm{Fe}$ and $\mathrm{S}$.

The effectiveness of the CME treatment at acidic conditions was investigated next. After the CME treatment with $5 \mathrm{~mol} \mathrm{~m}{ }^{-3} \mathrm{Si}(\mathrm{cat})_{3}{ }^{2-}$, the pyrite sample was shaken in the leaching solution of different $\mathrm{pH}$ ranging from highly acidic to natural (0-6) for a week. The leached amounts of $\mathrm{Fe}$ and $\mathrm{S}$ in leachate of pyrite without and with $\mathrm{CME}$ treatment after one week leaching experiment is shown in Figure 3(A) and $(\mathrm{B})$ as a function of final $\mathrm{pH}$.

The results show that for the CME treated pyrite, the highest amount of leached Fe was around 5 $\mathrm{ppm}$ in the investigated $\mathrm{pH}$ region. For the un-treated pyrite, the leached amount of Fe was high at the low $\mathrm{pH}$ region: 35-40ppm, but the amount decreased at around $\mathrm{pH}$ 5. This may be due to the precipitation of $\mathrm{Fe}^{3+}$ as $\mathrm{Fe}(\mathrm{OH})_{3}$. In Figure 3(B), the amounts of $\mathrm{S}$ ion present in the leachates after one week show that the $\mathrm{S}$ leaching is insignificant $(<1 \mathrm{ppm})$ for the CME treated pyrite. The amount of $\mathrm{S}$ ion leached from the un-treated pyrite was higher $(6 \mathrm{ppm})$ than from that of CME treated pyrite in the investigated $\mathrm{pH}$ range (0-6). The results shown in Figure 3 indicate that even in the acidic $\mathrm{pH}$ range, pyrite oxidation was suppressed successfully by CME treatment.

After one week leaching in different $\mathrm{pH}$, pyrite residue were collected and dried for analysis of the surface morphology analysis by SEM-EDX. The SEM image and elemental mapping for the pyrite residues pyrite without and with CME treatment are shown in Figure 4. The homogeneous existence of $\mathrm{Si}$ on the surface of CME treated pyrite leached at ph 2.98, supports the formation of $\mathrm{SiO}_{2} / \mathrm{Si}(\mathrm{OH})_{4}$ layer on pyrite by CME and the stability of the layer at low $\mathrm{pH}$. Comparatively weak signals of Si for non treated pyrite sample are obtained, which may be due to the Si contained in the pyrite itself. The coating formed by CME endured itself and inhibited the Fe and $\mathrm{S}$ leaching at very low $\mathrm{pH}$ of 2.98. Sustainability 
of $\mathrm{CME}$ coating at highly acidic $\mathrm{pH}$ condition verifies that $\mathrm{CME}$ is a suitable technique for suppression of pyrite oxidation.

The presence of iron oxidizing bacteria (Acidithiobacillus ferrooxidans) may also enhance the spontaneous pyrite oxidation [Temple and Colmer, 1951]. In this context, the effectiveness of CME coating was investigated in the presence of iron oxidizing bacteria. One month shaking flask experiment on the CME treated (with $5 \mathrm{~mol} \mathrm{~m}^{-3} \mathrm{Si}(\mathrm{cat})_{3}{ }^{2-}$ ) and un-treated pyrite was done in presence of Acidithiobacillus ferrooxidan; the results of the $\mathrm{pH}$ profile, amounts of Fe and $\mathrm{S}$ leached at 1 week intervals are presented in Figures 5 (A) (B) (C).

Figure 5 (A) shows the $\mathrm{pH}$ profiles of the leachates of pyrite with and without CME in the presence of iron oxidizing bacteria-Acidithiobacillus ferrooxidans. It shows that CME could control the $\mathrm{pH}$ drop even in the presence of iron-oxidizing bacteria. Comparing the results of with and without CME treatment, the $\mathrm{pH}$ values of the leachate of CME treated pyrite were over 2.3 throughout the investigated time period, where the $\mathrm{pH}$ of the leachate of the un-treated pyrite were lower and drops down to 1.8 at the fourth week.

In Figure 5(B) and (C) show the amount of Fe and $\mathrm{S}$ leached from the pyrite with and without CME treatment as a function of time respectively. In Figure 5(B) the amount of Fe present in the leachate for non treated pyrite after four weeks is almost twice as of in the CME treated pyrite leachate: the leached amount of Fe from the un-treated pyrite increased with passing weeks and was 750ppm, but only 350ppm from the CME treated pyrite after four weeks. In Figure 5(C) the behavior of S leaching from pyrite with and without CME treatment is depicted. The sulfur leaching for non treated pyrite is almost double than that of CME treated pyrite after four weeks. Continuous extraction of $\mathrm{S}$ was observed from the un-treated pyrite and $S$ concentration in the leachate reached $24 \mathrm{ppm}$ at five weeks contrary to less than 10ppm in the leachate of the CME treated pyrite. These results show that the Fe and S leaching was successfully suppressed by the CME treatment even in the presence of ample amount of iron oxidizing bacteria. Therefore it can be stated that the presence of bacteria would not hinder suppression of pyrite oxidation by the CME.

\section{CONCLUSION}

In this study, carrier-microencapsulation $(\mathrm{CME})$ using $\mathrm{Si}$ and catechol $\left[\mathrm{Si}(\mathrm{cat})_{3}{ }^{2-}\right.$ ] was proposed for preventing pyrite oxidation and was demonstrated by shaking flask leaching experiments. The $\mathrm{Si}(\mathrm{OH})_{4}$ or $\mathrm{SiO}_{2}$ coating made by $\mathrm{CME}$ treatment was found to be effective in controlling $\mathrm{pH}$ drop over one month experiment. The $\mathrm{Fe}$ and $\mathrm{S}$ leachability was also suppressed by the CME treatment. The suppressive effect of CME coating was effective even in the acidic $\mathrm{pH}$ range (pH 0-6) and even in the presence of iron oxidizing bacteria.

\section{REFERENCES}

N. Kafui, N. O. Egiebor, Control of pyrite oxidation by phosphate coating, The Science of the Total Environment, 162(1995)225-237.

K.L. Temple, A.R. Colmer, The autotrophic oxidation of iron by a new bacterium: Thiobacillus ferroxidans, J. Bacterial, 62(1951) 605-611.

M.J. Logsdon, ARD in hard-rock mining: a geochemical introduction, Mining Environmental Management (2002) 7-8.

M.P. Fillion, L.L. Siriois, K.Ferguson, Acid Mine drainage research in Canada, CIM bulletin.83944(1990) 33-40. 
M. Brown, B. Barley, H. Wood, mine water treatment: technology, application and policy, International Water Association Publishing (2002).

W.D. Robertson, The physical Hydrogeology of mill-tailings impoundments, Environmental geochemistry of sulfide mine-waste, eds. J.L. Jambor and D.W. Blowes, Mineral Association of Canada, Short course vol.22(1994) 1-17.

D.A. Swanson, S.L. Barbour, G.W. Wilson, Dry-site versus wet-site cover design, Proceedings of the Fourth International Conference on Acid Rock Drainage, May 30-June 6, 1997, Vancouver, B.C. vol. IV (1997), 1595-1610.

P.R. Dugan, Prevention of formation of acid mine drainage from high sulfur coal refuse by inhibition of iron and sulfur oxidizing microorganisms II. Inhibition of Run of Mine refuse under simulated field conditions, Biotechnology and Bioengineering, 29(1987)49-54.

S. Chander, R. Zhou, Effect of organic additives on acid mine generation from pyrite waste, Proceedings of the symposium on emerging process technologies for cleaner environment, Phoenix,Arizona, USA, Feb 24-27,131-139.

D.M. Kargbo, G. Atallah, S. Chatterjee, Inhibition of pyrite oxidation by a phospholipid in the presence of silicate, Environmental science and technology,38(2004) 3432-3441.

V.P. Evangelou, Pyrite oxidation and its control, CRC press, Boca Raton, (1995) 80-81.

V.P. Evangelou, Pyrite microencapsulation technologies: principles and potential field application, Ecological Engineering. 17(2001), 165-178.

Murdock, D.J., Fox, J.R.W., Bensley, J.G., Treatment of acid mine drainage by the high density sludge process. In: Proceedings of the International Land Reclamation and Mine Drainage Conference and Third International Conference on the Abatement of Acid Drainage, Pittsburgh, April, vol. 1, (1994) , 241-249.

McDonald, D.M., Webb, J.A., Musgrave, R.J., 2006. The effect of neutralization method and reagent on the rate of $\mathrm{Cu}$ and $\mathrm{Zn}$ release from acid rock drainage treatment sludge, In: Proceedings of the 7th ICARD, St. Louis, MO, USA, March, 1198-1218.

J. Satur, N. Hiroyoshi, M. Tsunekawa, M. Ito, H. Okamoto. Carrier-microencapsulation for preventing pyrite oxidation, International Journal of Mineral Processing, 83:3-4, (2007)116-124.

R.K.T. Jha, J. Satur, N. Hiroyoshi, M. Ito, M. Tsunekawa, Carrier-microencapsulation using Si-catechol complex for suppressing pyrite floatability, Minerals Engineering, 21:12-14 ( 2008) 889-893.

K. Sasaki, M. Tsunekawa, T. Ohtsuka, H. Konno, Confirmation of a sulfur-rich layer on pyrite after oxidative dissolution by Fe(III) ions around pH 2, Geochimica et Cosmochimica Acta, 59 (1995) 31553158.

R. Rodriguez , M.A. Blesa, A.E. Regazzoni, Surface complexation at the $\mathrm{TiO}_{2} /$ aqueous solution interface: chemisorptions of catechol, Journal of colloid and interface science. 177 (1996) 122-131.

M. J. Caulfield, T. Russo, D. H. Solomon, Complexes of Benzene-1,2-diol Mannich Bases.Novel Hexacoordinate Zwitterionic Silicon(IV) Complexes, Australian Journal of Chemistry, 54:6(2001),375381.

P. Kansal, R.M. Laine, Pentacoordinate silicon complexes as precursors to silicate-grasses and ceramics, Journal of the American Ceramic Society, 77:4 (1994) 875-882. 
FIGURE CAPTIONS
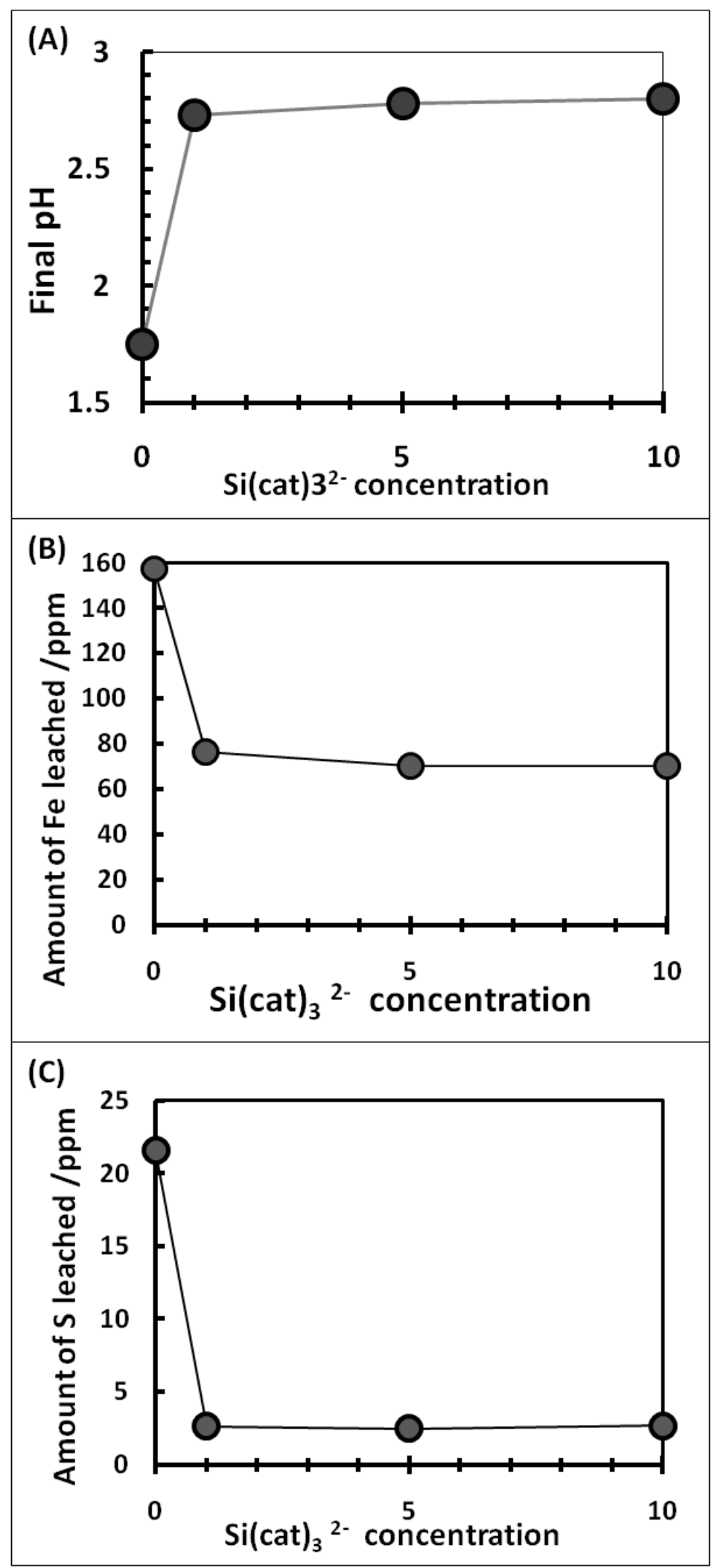

Figure 1: (A) Final pH of the leachate, (B) amount of Fe (in ppm) present in the leachate, and (C) amount of S(in ppm) present in the leachate, obtained after four week of shaking flask experiment as function of $\mathrm{Si}(\mathrm{cat}){ }_{3}{ }^{2-}$ concentration. CME treatment time was $1 \mathrm{~h}$. 

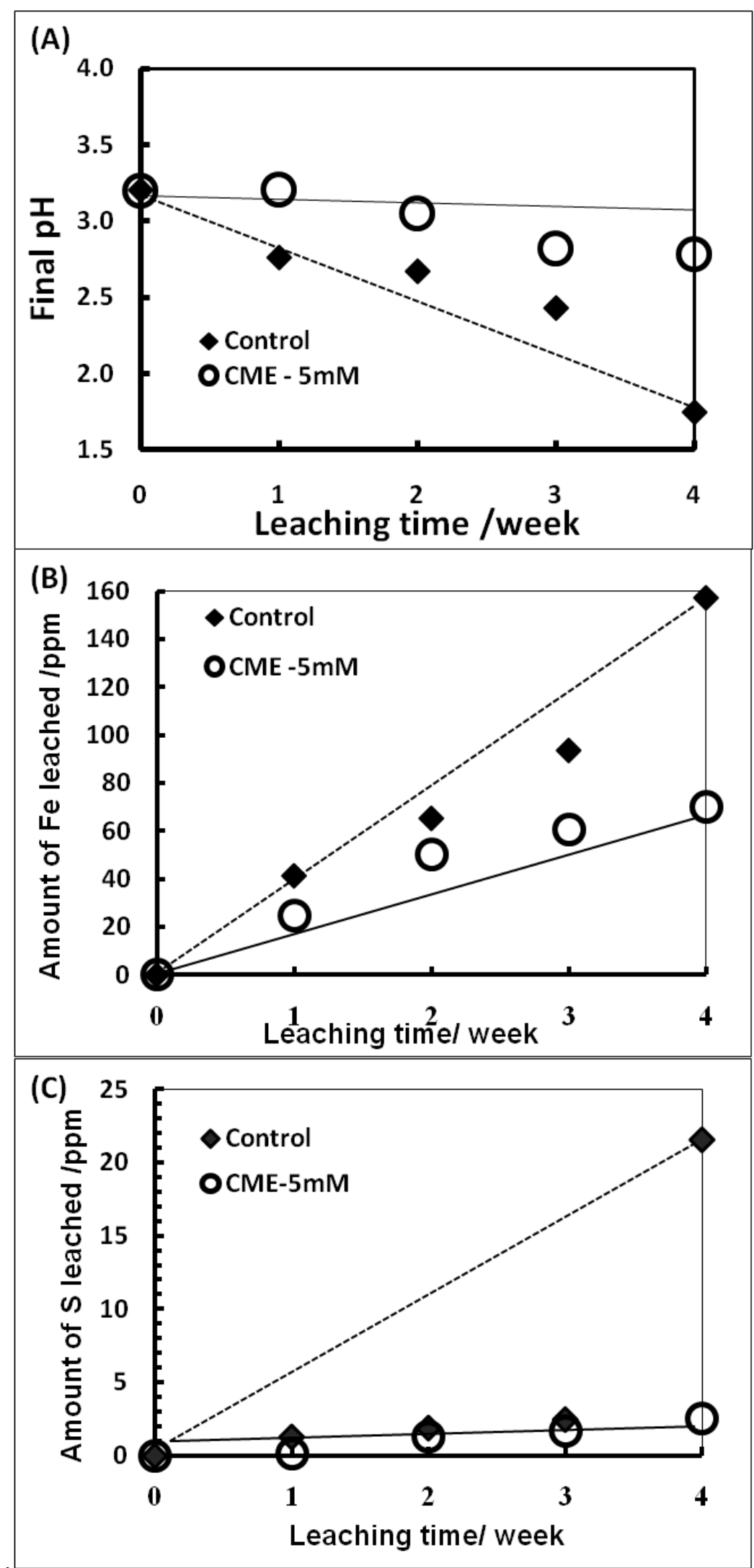

Figure 2: (A) pH profile of the leachate, (B) amount of Fe (in ppm) and (C) amount of S (in ppm) in the leachate of pyrite without and with $\mathrm{CME}$ treatment, obtained from shaking flask experiments for one month at one week interval. 

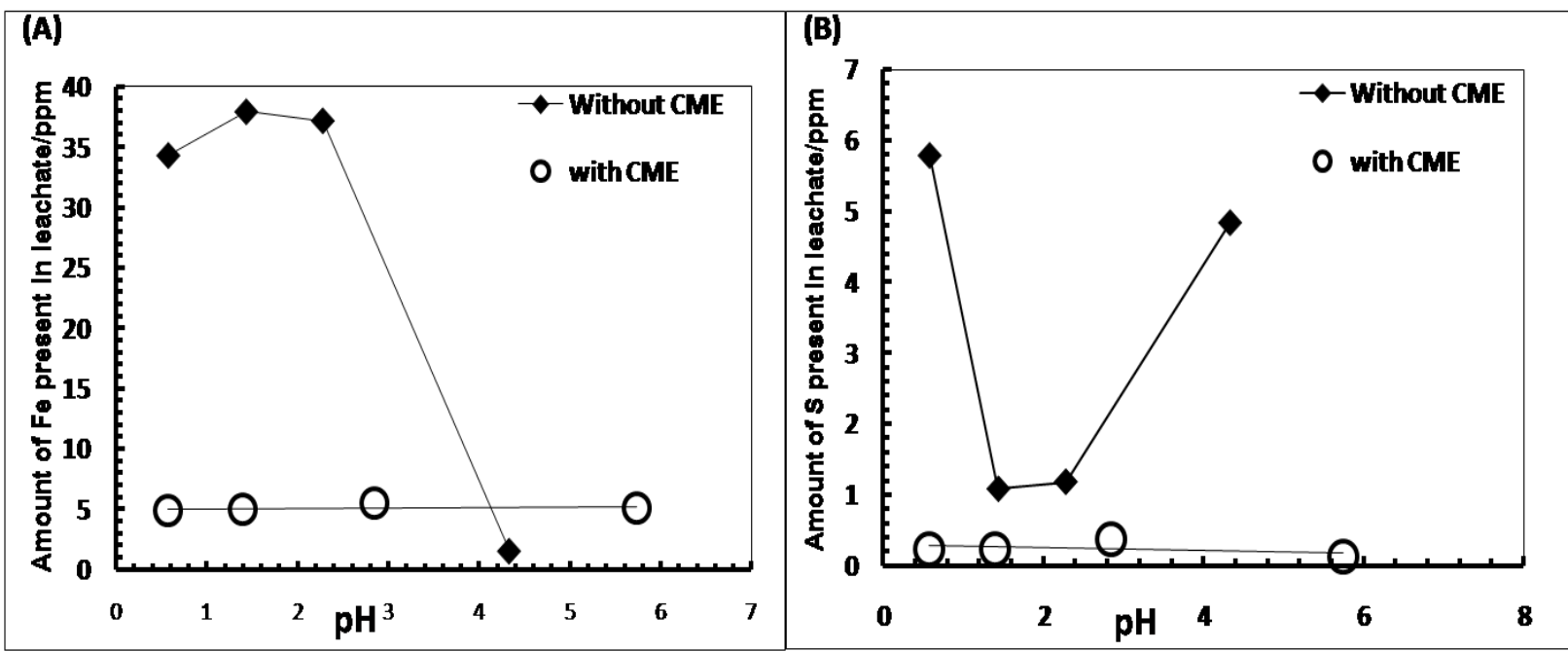

Figure 3: (A) Amount of Fe (in ppm) and (B) amount of S (in ppm) present in the leachates of pyrite without and with CME treatment after 1 week shaking flask leaching experiment at acidic to natural $\mathrm{pH}$. The $\mathrm{Si}(\text { cat })_{3}{ }^{2-}$ concentration was $5 \mathrm{~mol} \mathrm{~m}^{-3}$. 

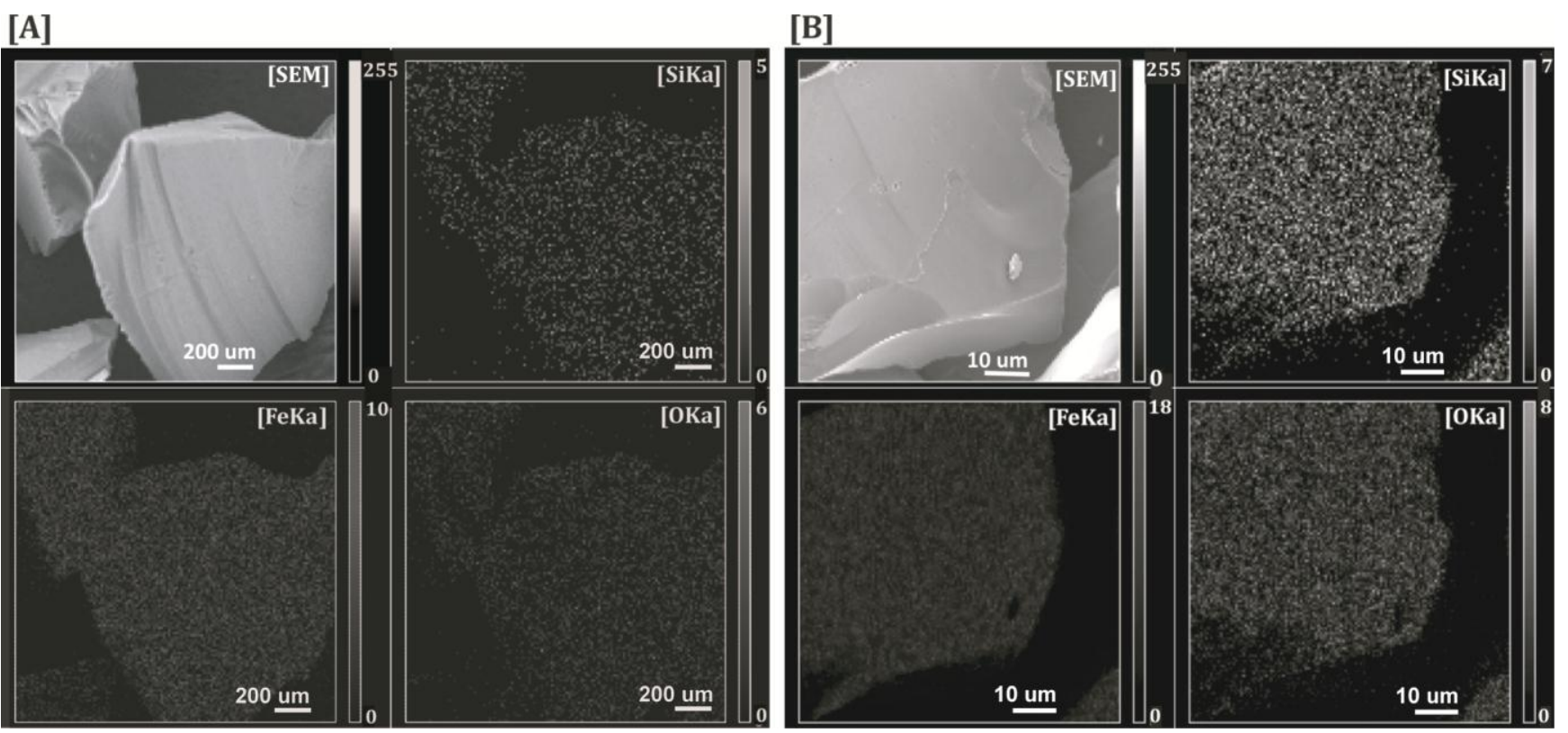

Figure 4: SEM image and EDX mapping for elements on the pyrite particle leached in low $\mathrm{pH}$ for 1 week in aerobic condition. (A) Pyrite without CME treatment, leachate $\mathrm{pH}$ was 2.34. (B) Pyrite with CME treatment, leachate $\mathrm{pH}$ was 2.98 . The $\mathrm{Si}(\mathrm{cat})_{3}{ }^{2-}$ concentration was $5 \mathrm{~mol} \mathrm{~m}^{-3}$. 

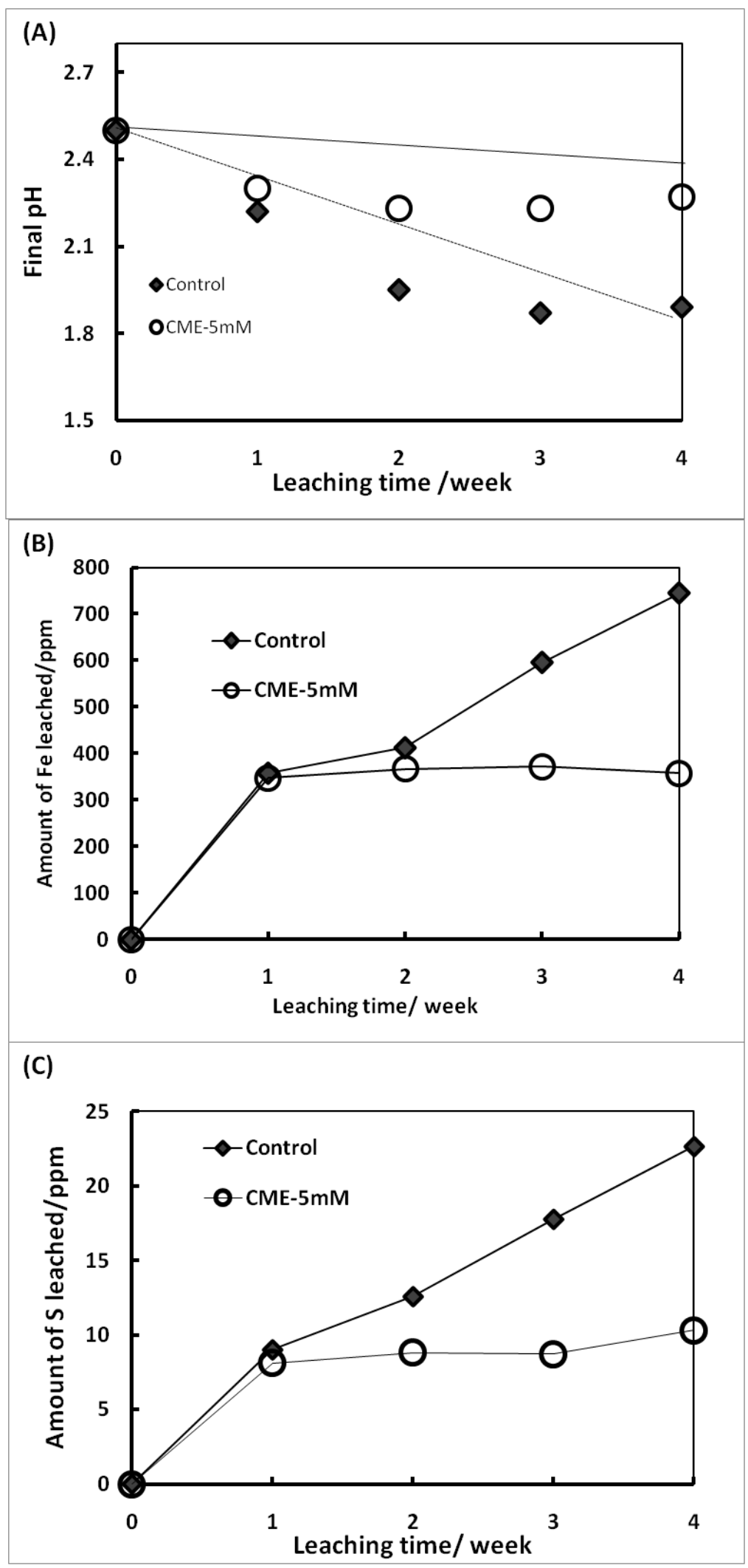

Figure 5: (A) $\mathrm{pH}$ profile of leachate of pyrite with and without CME (B) amount of Fe and (C) amount of $\mathrm{S}$ present in the leachate of pyrite with and without $\mathrm{CME}$ treatment shaken in the presence of iron

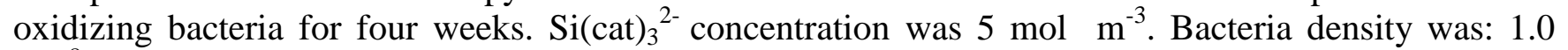
$\mathrm{x} 10^{8}$ cells $/ \mathrm{ml}$. 